\title{
FENOMENA CINTA LESBIAN
}

\author{
Anita Susanti ${ }^{1}$, Mochamad Widjanarko \\ ${ }^{1,2)}$ Fakultas Psikologi Universitas Muria Kudus \\ Kampus Universitas Muria Kudus, Gondangmanis, Kudus, Jawa Tengah \\ m.widjanarko@umk.ac.id
}

\begin{abstract}
The aims of this research is to describe the love phenomenon of lesbians in the Kudus Regency. The subjects were three lesbian individuals living in Kudus. The research method was phenomenology which based on the subjective experience or phenomenological experience. The data collecting techniques were observation and interview. This study applied snowball sampling technique, meaning that the sample was carried out serially by asking information from previously interviewed subject. The data analysis method was matrix by Miles \& Hubberman consisting of three stages of simultanious activities, they were: data reduction, data presentation and conclusion or verification. The result shows that two lesbians have experienced lesbian love previously but one subject has experienced lesbian love for the first time. There are intimacy, passion and commitment in lesbian love. There is conflict in their relationship but there is also hope for their future lesbian love relationship.
\end{abstract}

Keywords: love, lesbian, phenomenology

\section{Abstrak}

Tujuan penelitian ini adalah untuk menjelaskan fenomena cinta lesbian di kota Kudus. Adapun subjek dalam penelitian ini adalah tiga orang lesbian yang berdomisili di kota Kudus. Metode yang digunakan dalam penelitian ini adalah metode penelitian kualitatif dengan pendekatan fenomenologis mengunakan teknik pengumpulan data observasi dan wawancara. Teknik pengambilan sampel menggunakan teknik snowball sampling, artinya pengambilan sampel dilakukan secara berantai dengan meminta informasi pada orang yang telah diwawancarai atau dihubungi sebelumnya. Sedangkan metode analisis data menggunakan matriks oleh Miles \& Hubberman yang terdiri dari tiga alur kegiatan yang terjadi secara bersamaan yaitu: reduksi data, penyajian data, dan penarikan kesimpulan atau verifikasi. Hasil penelitian menunjukkan bahwa pengalaman cinta lesbian pernah dialami sebelumnya oleh kedua subjek sedangkan satu subjek baru pertama kali mengalaminya. Dalam cinta lesbian terdapat keintiman, hasrat dan komitmen. Kemudian muncul konflik yang berpengaruh pada hubungannya. Tetapi muncul juga harapan mengenai masa depan lesbian terutama mengenai cinta mereka.

Kata kunci: cinta, lesbian, fenomenologi

\section{PENDAHULUAN}

Selain di kota-kota besar, seperti Jakarta, Surabaya dan Yogyakarta keberadaan individu yang memiliki orientasi seksual seperti lesbian ternyata juga ada di kota kabupaten seperti Kudus, yang merupakan salah satu kota di Jawa Tengah. Kudus dikenal sebagai kota wali karena terdapat tempat-tempat bersejarah bagi umat Islam dan sekaligus menjadi objek ziarah yaitu menara Kudus dengan makam Sunan Kudus dan di lereng pegunungan Muria, ter- dapat makam Sunan Muria. Sunan Kudus dan Sunan Muria adalah dua di antara sembilan wali atau penyebar agama Islam di Jawa. Hal ini menyebabkan masyarakat Kudus mempunyai ikatan sejarah dan kultural dengan para wali dan dikenal sebagai kota yang religius, identik dengan kota santri, dan sejak berdirinya merupakan bagian dari rangkaian penyebaran Islam di Jawa. 

Kodrat manusia diciptakan berpasangpasangan antara laki-laki dan perempuan untuk membangun sebuah keluarga yang harmonis (Budiarty, 2011). Idealnya seorang lelaki akan berpasangan dan jatuh cinta pada seorang wanita begitu pula sebaliknya wanita idealnya berpasangan dan jatuh cinta pada seorang lelaki. Seperti sebuah keluarga terdiri dari seorang ayah yang berjenis kelamin lelaki, seorang ibu yang berjenis kelamin wanita dan memainkan perannya sesuai dengan jenis kelaminnya (Novena, 2011).

Budiarty (2011) menyebutkan bahwa dalam kehidupan masyarakat terdapat permasalahan-permasalahan yang begitu komplesks, muncul suatu hal berbeda serta dianggap tidak wajar, dikarenakan dua insan yang sejenis menjalin hubungan percintaan yang dikenal dengan homoseksual wanita atau lesbian. Homoseksual adalah kelainan terhadap orientasi seksual yang ditandai dengan timbulnya rasa suka terhadap orang lain yang mempunyai jenis kelamin yang sejenis atau identitas gender yang sama (Handayani, 2010).

Carol (dalam Prima \& Ika, 2011) mengatakan orientasi seksual merupakan istilah yang mengarah kepada jenis kelamin, yang ditandai dengan ketertarikan secara emosional, fisik, seksual dan cinta yang bertahan lama terhadap individu tersebut. Orientasi seksual terbagi tiga yaitu heteroseksual, homoseksual dan biseksual. Heteroseksual merujuk kepada ketertarikan terhadap jenis kelamin yang berbeda, sementara itu homoseksual merujuk kepada ketertarikan terhadap jenis kelamin yang sama dan biseksual merujuk kepada ketertarikan kepada kedua jenis kelamin. Heteroseksual disebut juga dengan istilah straight, sedangkan pria homoseksual dikenal dengan istilah gay, dan wanita homoseksual disebut dengan lesbian.
Fenomena lesbian kini semakin marak di Indonesia, terutama di kota-kota besar. Di Indonesia sendiri, data statistik menyatakan bahwa 8 dari 10 juta populasi pria Indonesia pada suatu waktu pernah terlibat pengalaman homoseksual. Hasil survai YPKN (Yayasan Pendidikan Kartini Nusantara) menunjukkan, ada 4000 hingga 5000 penyuka sesama jenis di Jakarta. Sedangkan Gaya Nusantara memperkirakan, 260.000 dari enam juta penduduk Jawa Timur adalah homo. Angka-angka itu belum termasuk kaum homo di kota-kota besar lainnya (Gatra dalam Mutmainnah \& Ismi, 2012).

Penelitian Kinsey (dalam Nurkholis, 2013) menyebutkan bahwa di Amerika Serikat, prevalensi mereka yang homoseksual murni $(100 \%)$ berkisar antara $2 \%$ sampai $4 \%$, sementara yang lebih menonjol homoseksual daripada heteroseksual berkisar antara 7\% hingga 13\% atau dengan kata lain diperkirakan terdapat $10 \%$ dimensi homoseksual yang cukup berarti dalam kehidupan masyarakat modern dan industri. Berdasarkan penelitian yang dilakukan Kinsey pada remaja berusia 20 tahun, terdapat 17\% perempuan mempunyai pengalaman lesbian kemudian pada penelitian yang dilakukan terhadap remaja berusia 16-19 tahun, terdapat 6 persen wanita lesbian (Soewandi, 2012).

Kota seperti Kudus, di dalamnya terdapat lesbian yang berada di tengah-tengah masyarakat. Mereka berbaur dengan masyarakat untuk tetap bisa bersosialisai dan diterima di masyarakat. Penulis tertarik untuk mengkaji perilaku seks lesbian, fokus utamanya yaitu cinta di antara lesbian. Seseorang dengan orientasi homoseksual (lesbian) jatuh cinta karena merasa memiliki kesamaan jenis kelamin.

Walaupun belum terbuka, fenomena cinta lesbian di Kudus, bisa diungkapkan 
melalui cerita U sebagai berikut:

"Saya melakukan sesuatu
sesuai dengan lingkungan di
mana ketika berada di
lingkungan heteroseksual, saya
akan bersikap biasa tapi ketika
berada dalam lingkungan
lesbian saya akan menunjukkan
jati diri saya sebagai lesbian.
Hal ini saya lakukan karena
tidak ingin keluarga sampai
tahu dan saya tetap bisa
bersosialisasi dengan
lingkungan. Jadi hanya sesama
kaum lesbian yang sering
kumpul mengetahui tentang
orientasi saya” (Wawancara,
14 Juni 2013).

Begitu juga dengan penuturan $\mathrm{N}$ di bawah ini,

"Kedua orang tua saya tidak
mengetahui tentang orientasi
seksual saya. Hanya dengan
sesama kaum lesbian dan
teman-teman dekatnya yang
mengetahui bahwa saya
seorang lesbian. Saya
melakukan ini agar tetap bisa
berbaur dan bersosialisasi
dengan lingkungan"

(Wawancara, 2 Oktober 2013).

Cinta lesbian pada dasarnya sama dengan cinta heteroseksual, di dalam cinta itu juga terdapat beberapa komponen yang menyertainya. Dalam teorinya triangular theory of love, Sternberg (dalam Marasabessy, 2008) mengemukakan bahwa cinta memiliki tiga komponen: pertama, keintiman (intimacy) perasaan dalam suatu hubungan yang meningkatkan kedekatan, keterikatan, dan keterkaitan. Kedua, hasrat (passion) meliputi rasa kerinduan yang dalam untuk bersatu dengan orang yang dicintai yang merupakan ekspresi hasrat dan kebutuhan seksual. Ketiga, komitmen/ keputusan (commitment/ decision) suatu keputusan untuk mencintai seseorang, menjaga cinta itu dan ketetapan seseorang untuk bertahan bersama sesuatu atau seseorang sampai akhir.

Berdasarkan pendapat Sternberg (1997) di atas dapat disimpulkan bahwa ketiga komponen tersebut saling berkaitan dan tidak selalu harus dimulai secara berurutan seperti di atas. Misalnya hasrat seksual dapat muncul karena adanya keintiman, atau sebaliknya, pemenuhan hasrat seksual yang baik akan menghasilkan keintiman. Dengan demikian, kedua komponen ini hampir selalu berinteraksi satu sama lain dalam hubungan dekat dan dalam komponen keputusan atau komitmen tidak selalu ada secara bersamaan. Ketiga komponen di atas mungkin memiliki kekuatan yang berbeda-beda dalam suatu hubungan. Dan ekspresi dari berbagai kebutuhan ketiga komponen cinta ini juga berbeda antara satu individu dengan individu lain bahkan antara dua individu yang bercinta mungkin akan berbeda pula.

Dihubungkan dengan konsep cinta, penulis tertarik untuk meneliti cinta lesbian yang ada di kota Kudus. Sternberg (1986) melandasi atas hubungan antara pria dan wanita, sehingga perlu penelitian mengenai cinta homoseksual yang dalam penelitian ini difokuskan pada cinta lesbian di Kudus.

\section{METODE}

Penelitian ini menggunakan metode kualitatif dengan pendekatan fenomenologis. Subjek dalam penelitian ini adalah lesbian yang berdomisili di Kudus, berusia 21-30 tahun. Dalam prosedur pengambilan sampel penelitian ini menggunakan teknik bola salju (snowball sampling), penulis bertemu dengan komunitas lesbian dari satu subjek kemudian mendapatkan subjek yang lain dengan cara disarankan subjek 
pertama. Pengambilan data melalui observasi dan wawancara. Analisis data menggunakan menggunakan matriks oleh Miles \& Hubberman (1992) yang terdiri dari tiga alur kegiatan yang terjadi secara bersamaan yaitu: reduksi data, penyajian data, penarikan kesimpulan atau verifikasi. Kredibilitas hasil penelitian dilakukan dengan menggunakan ketekunan pengamatan, uraian rinci, pengecekan anggota serta checking dan rechecking data.

\section{HASIL DAN PEMBAHASAN}

Cinta diyakini sebagai salah satu bentuk emosi yang sangat penting bagi manusia (Roediger dkk. dalam Saragih \& Irmawati, 2005). Jatuh cinta umumnya terjadi antara laki-laki dan perempuan, akan tetapi kaum homoseksual juga mengalami hal ini (Setiawan, 2011).

Cinta lesbian di abad ke-21 telah memasuki era baru dalam masa bagaimana hal itu dirasakan dan digambarkan secara terang-terangan berkumpul di suatu tempat, menjadi komunitas yang terbuka. Perkembangan komunitas lesbian modern di akhir abad ke-21 ketika lesbian mulai merayakan sensualitas, bahaya, intensitas, dan kenyamanan cinta antara perempuan di depan umum. Para lesbian yang terpelajar juga membenarkan catatan sejarah dengan menggunakan surat-surat cinta dan puisi dari berbagai abad yang mana menunjukkan gairah, kehangatan, dan kasih sayang dari cinta lesbian (Rose \& Eaton, 2012).

Pada umumnya, cinta seorang lesbian itu sangat mendalam dan lebih hebat dari pada cinta heteroseksual. Meskipun pada relasi lesbian, tidak didapatkan kepuasan seksual yang wajar. Cinta lesbian juga biasanya lebih hebat daripada cinta homoseksual diantara kaum pria. Elemen erotik dan nafsu-nafsu dahsyat yang bergelora pada cinta lesbian itu pada umumnya jauh lebih intensif daripada nafsu heteroseksual (Kartono, 1989).

Hal ini seperti yang diceritakan subjek A sebagai berikut:

"Nyaman, aku lebih nyamanya sama dia, kalau pas aku lagi marah sama dia aku ngeliat dia tuuu....tu marah $\mathrm{ku}$ tu jadi ilaaang...jadi berkuraaang nggak tahu kenapa. Pengen marah tapi nggak bisaa. Dulu waktu awal-awal deg-degan.....trus kalau lama nggak ketemu dia trus ketemu dia tu rasanya tenaang banget. Aku yakin aku gak bisa pisah sama dia $100 \%$ gak bisa pisah sama dia. Kalaupun nantinya aku harus pisah aku mesti gak bisa lepas pas sama dia gak bisa, selalu ingin tahu keberadanya selalu ingin tahu kabar dia pokoknya semua tentang dia, aku ingin tahu” (Wawancara, 10 Oktober 2013).

Penelitian pada pasangan lesbian menunjukkan bahwa hubungan yang sukses ketika memiliki kualitas yang berfungsi sama seperti dalam hubungan heteroseksual (Scrivner, Eldridge \& Kurdek dalam Rose \& Eaton, 2012). Namun sama halnya dengan heteroseksual, homoseksual (lesbian) juga mengalami berbagai permasalahan dengan cinta yang mereka miliki. Peterson (dalam Nurmala, Anam, Suyono, 2006) mengatakan konflik sering terjadi dalam hubungan yang erat.

Saat penulis melakukan preliminary interview dengan teman subjek penelitian, didapatkan pengalaman yang menarik untuk diteliti berkaitan dengan cinta dalam lesbian, seperti yang dialami perempuan bernama $\mathrm{D}$, seperti ini penuturannya: 
"Saya mencintai sahabat perempuan saya, namun timbul dilema berkaitan dengan cinta yang saya miliki. Saya tidak tahu bagaimana bisa hidup jauh dari sahabat yang sangat saya cintai, saya juga takut ditinggalkan oleh sahabat saya" (Wawancara, 18 September 2013).

Hal yang nyaris sama juga dialami oleh $\mathrm{N}$.

"Saya merasa takut dan
berfikir kalau perempuan
dengan perempuan,
bagaimana nanti selanjutnya.
Saya sudah terlanjur sayang
dan mencintai teman
perempuan saya. Saya sering
cemburu karena takut
kehilangan dan tidak yakin
tentang perasaan pasangan
saya" (Wawancara, 2 Oktober
2013).

Dari hasil wawancara dengan di atas, terlihat bahwa $\mathrm{D}$ dan $\mathrm{N}$ memiliki permasalahan yang sama berkaitan dengan cinta mereka. Pengimplementasian cinta pada setiap individu akan berbeda, terutama pada kaum homoseksual. Karena tertarik pada orang dari jenis kelamin yang sama, ekspresi ketertarikannya terpaksa dilakukan secara sembunyi-sembunyi (Nugroho dalam Fandina, 2012). Di Kudus, banyak terdapat cerita tentang kehidupan masyarakat beserta pemasalahannya, termasuk dunia lesbian yang terjadi di kalangan perempuan.

\section{Cerita Cinta A}

Ketertarikannya terhadap sesama jenis sudah terlihat ketika A usia remaja, namun subjek belum menyadarinya sampai ketika subjek berada di dunia kerja dan menyadari bahwa dirinya seorang lesbian yang mencintai teman kerjanya. Pengalaman cinta dengan sesama jenis merupakan yang pertama kalinya bagi subjek.

Pada hubungan cinta lesbiannya, subjek mencapai dua level keintiman meliputi subdimensi baik untuk saya, merasakan kenyamanan dan ketenangan dengan pasangan, tidak bisa berpisah dengan pasangan \& selalu ingin bersama, merasa mendapat dukungan \& dorongan dari pasangan dan subdimensi pasangan spesial; menyukai kepribadian pasangan, menghargai pasangan dengan baik, memiliki keinginan untuk membahagiakan pasangan, menganggap penting orang yang dicintai.

Kemudian terdapat juga tiga dorongan hasrat berupa ketertarikan fisik, melakukan kontak fisik dan romansa. Ketertarikan fisik yaitu menyukai dan menikmati daya tarik fisik dari pasangan, kepuasan seksual. Melakukan kontak fisik dilakukan dari mulai berciuman sampai dengan berhubungan seksual dengan pasangan dan bisa merasakan kepuasan ketika melakukan hubungan seksual dengan melihat pasanganya mencapai klimaks. Sementara romansa yaitu merasa selalu terkait dan tidak bisa jauh dari pasangan.

Selain itu ada dua aspek komitmen berupa komitmen jangka pendek; merasakan dan mencintai pasangannya, komitmen jangka panjang; memiliki keinginan untuk mempertahankan dan berusaha tetap bersatu meskipun tahu bahwa pasangannya belum sepenuhnya mencintainya. Namun di samping itu juga muncul berbagai permasalahan di antaranya perselingkuhan, orang ketiga yang muncul dalam hubungan, perasaan cemburu karena pasangan masih bertemu dengan mantannya, tuntutan menikah yang datang dari keluarga subjek dan trauma dengan pasangan lawan jenis yang dirasakan subjek. 


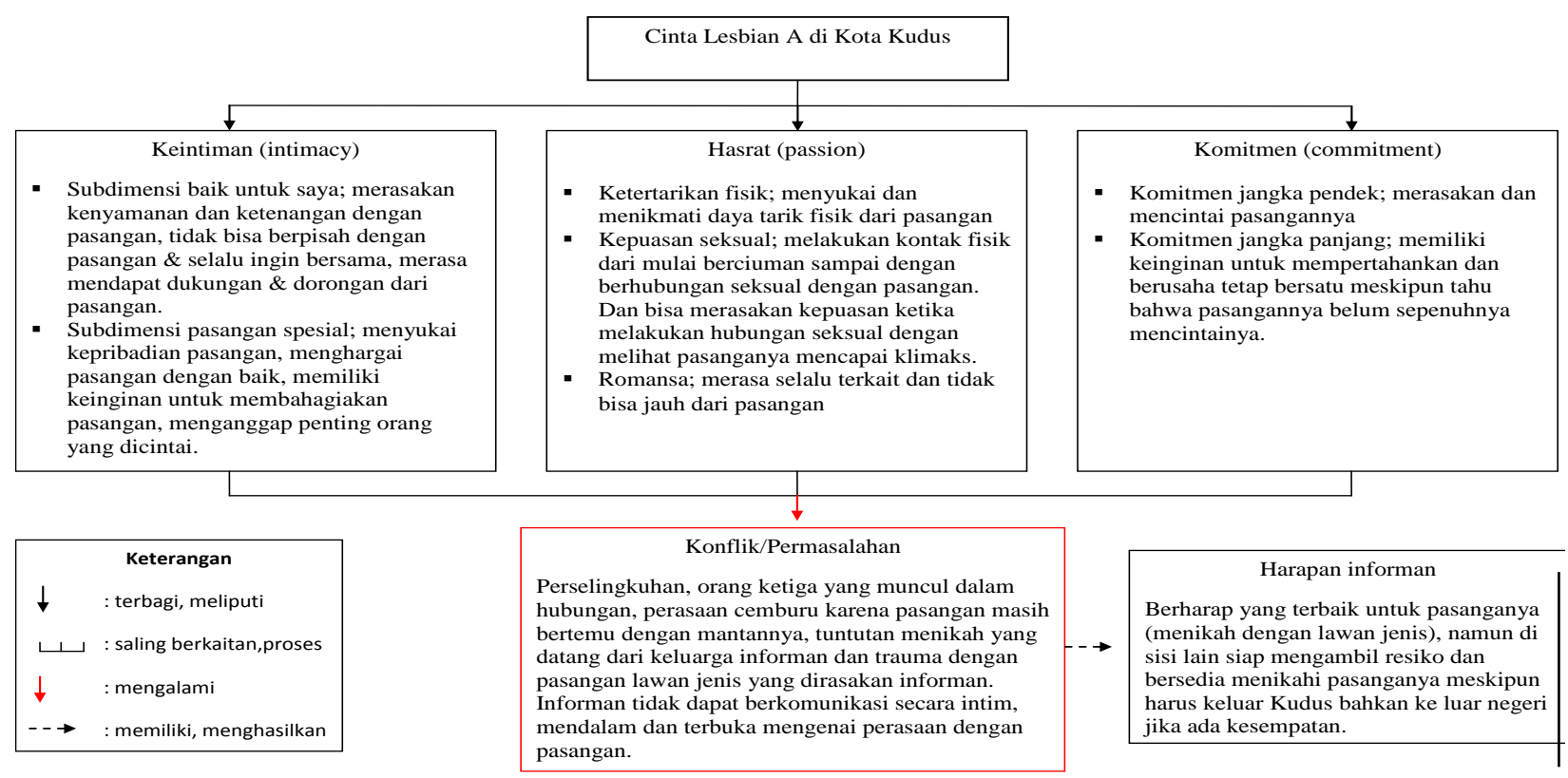

Gambar 1.

Skema Interpretasi Cinta A

Subjek tidak dapat berkomunikasi secara intim, mendalam dan terbuka mengenai perasaan dengan pasangan. Tetapi subjek berharap yang terbaik untuk pasanganya (menikah dengan lawan jenis), namun di sisi lain siap mengambil resiko dan bersedia menikahi pasanganya meskipun harus keluar dari Kudus bahkan ke luar negeri jika ada kesempatan. Skema Interpretasi Cinta A tergambar pada Gambar 1.

\section{Cerita Cinta B}

Pada subjek B, ketertarikannya terhadap sejenis muncul dari rasa kagum terhadap perempuan. Pengalaman cinta terhadap sesama jenis, juga dialami B sejak remaja. Subjek memiliki tujuh pengalaman cinta sampai dengan pasangannya yang sekarang. Dalam hubungan cinta lesbiannya, subjek mencapai tiga level keintiman meliputi subdimensi baik untuk saya; merasakan bahagia, ketenangan, \& kenyamanan ketika bersama dengan pasangan, merasa mendapat dukungan \& dorongan dari pasangan. Subdimensi pasangan spesial; menyukai kepribadian pasangan, menghargai pasangan dengan baik, memiliki keinginan untuk membahagiakan pasangan, menganggap penting orang yang dicintai, dan subdimensi baik untuk siapapun; saling mencintai \& terbuka untuk berbagi permasalahan satu sama lain.

Kemudian terdapat juga dua dorongan hasrat berupa ketertarikan fisik; menikmati daya tarik fisik dari pasangan, kepuasan seksual; melakukan kontak fisik dengan pasangan dari mulai berciuman sampai melakukan hubungan seksual. Bisa merasakan kepuasan dan mencapai klimaks dengan bergantian memuaskan satu sama lain. Dan dua aspek komitmen berupa komitmen jangka pendek; mengatakan cinta pada pasangan \& mencintai pasangannya, komitmen jangka panjang; ingin tetap berpacaran dan bisa 


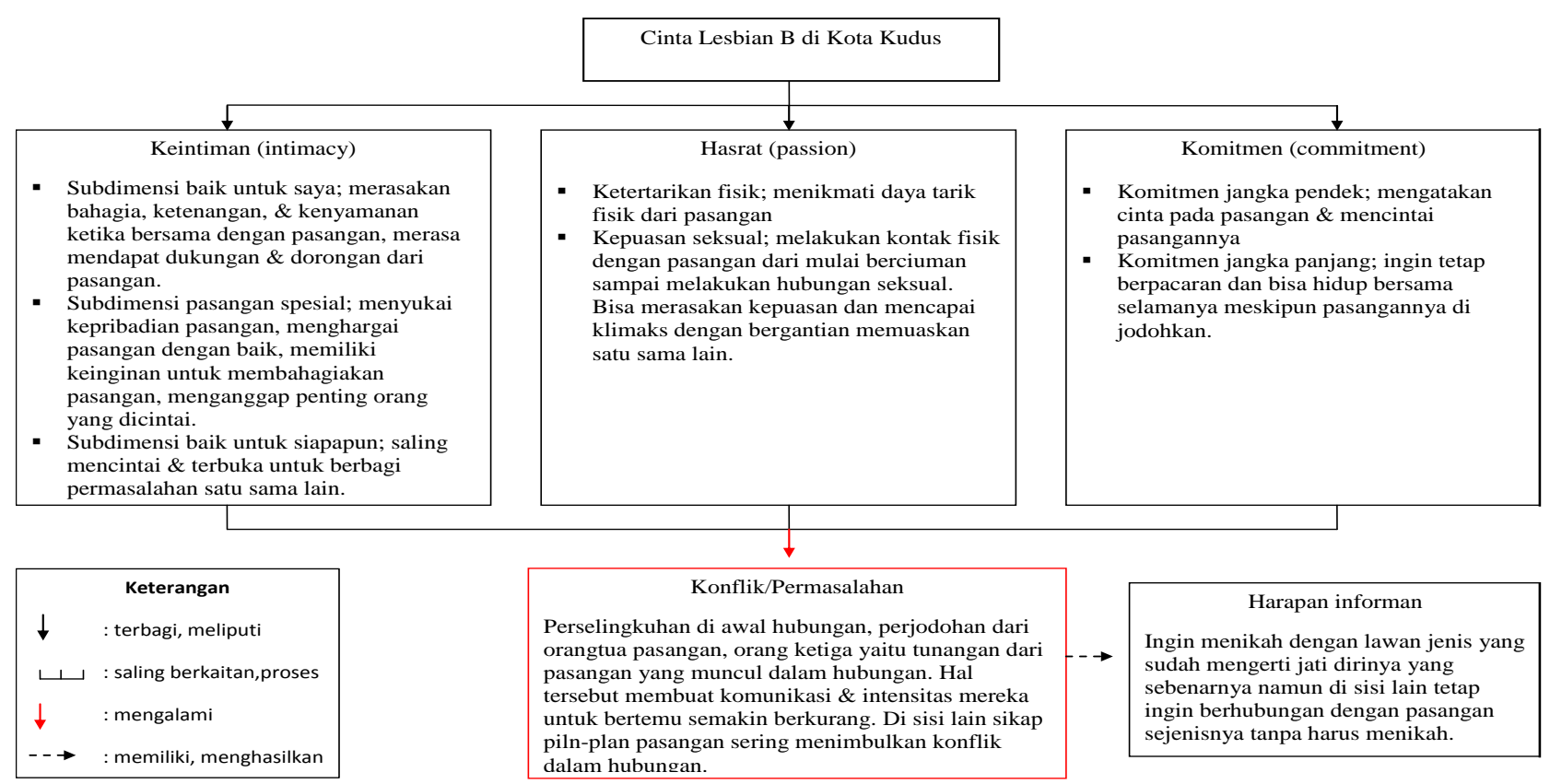

Gambar 2.

Skema Interpretasi Cinta B

hidup bersama selamanya meskipun pasangannya dijodohkan. Namun di samping itu juga muncul berbagai permasalahan diantaranya perselingkuhan di awal hubungan, perjodohan dari orangtua pasangan, orang ketiga yaitu tunangan dari pasangan yang muncul dalam hubungan. Hal tersebut membuat komunikasi \& intensitas mereka untuk bertemu semakin berkurang. Di sisi lain sikap plin-plan pasangan sering menimbulkan konflik dalam hubungan. Akan tetapi, di samping itu subjek juga masih memiliki harapan untuk bisa menikah dengan lawan jenis yang sudah mengerti jati dirinya yang sebenarnya namun di sisi lain tetap ingin berhubungan dengan pasangan sejenisnya tanpa harus menikah. Skema Interpretasi Cinta B tergambar pada gambar 2 .

\section{Cerita Cinta C}

Ketertarikannya dengan sesama jenis juga muncul ketika remaja. C merasa senang dekat dengan teman-teman perempuannya dan pernah bermimpi berciuman dengan teman perempuannya. Pengalaman cinta pertama dengan sejenis, dialami subjek ketika lulus sekolah tingkat SMP dan untuk pertama kalinya subjek memiliki pasangan sejenis. Subjek memiliki tiga pengalaman cinta dan dalam cinta lesbiannya yang sekarang. Dalam hubungan cinta lesbiannya, subjek mencapai dua level keintiman meliputi subdimensi baik untuk saya; mencoba menghargai pasangan karena tidak bisa sendiri, merasa mendapat dukungan dari pasangan. Subdimensi pasangan spesial; menyukai pribadi pasangan, mencoba membahagiakan pasangan dengan tetap bertahan untuk bersama sampai hubungannya tidak bisa dipertahankan.

Kemudian terdapat juga dua dorongan hasrat berupa ketertarikan fisik; menikmati daya tarik fisik dari pasangan, kepuasan seksual; melakukan kontak fisik dengan pasangan dari mulai berciuman sampai berhubungan seksual. Bahkan bisa 


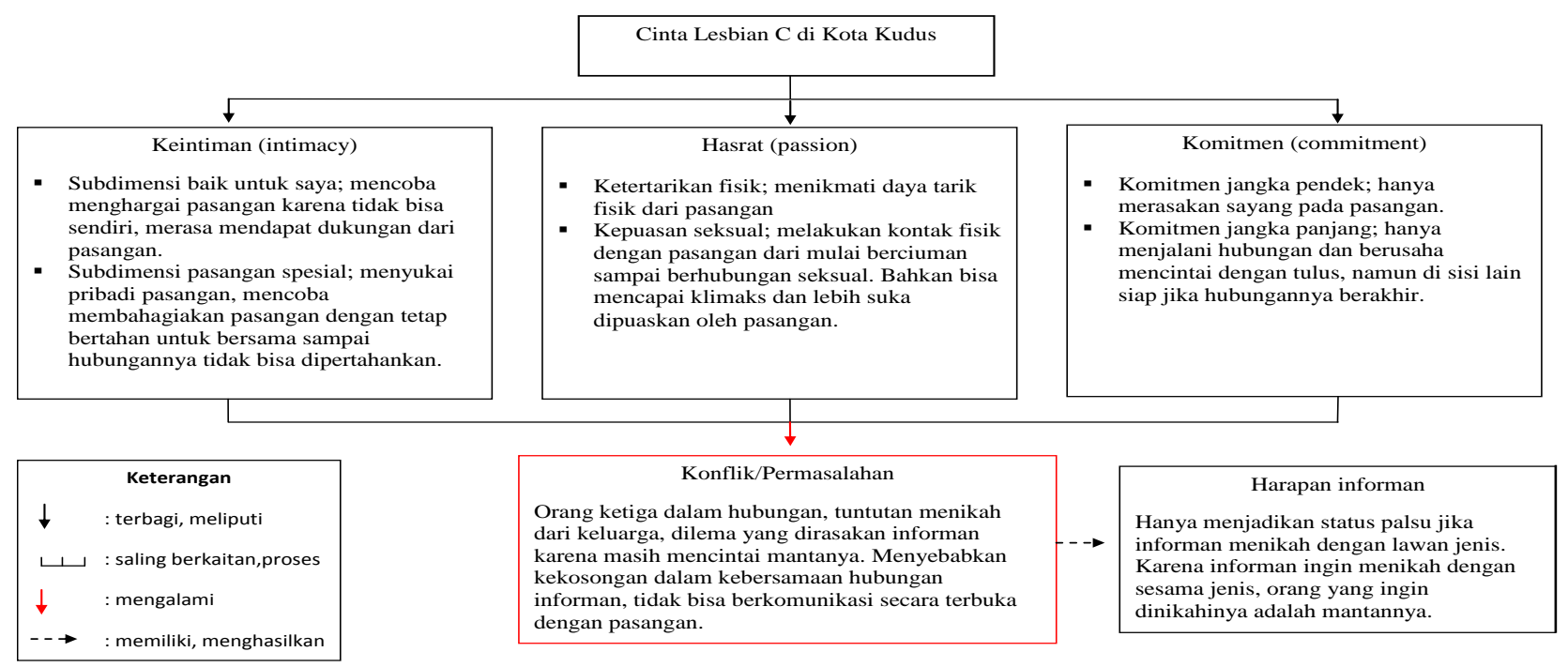

Gambar 3.

Skema Interpretasi Cinta C

mencapai klimaks dan lebih suka dipuaskan oleh pasangan. Dua aspek komitmen berupa komitmen jangka pendek; hanya merasakan sayang pada pasangan, komitmen jangka panjang; hanya menjalani hubungan dan berusaha mencintai dengan tulus, namun di sisi lain siap jika hubungannya berakhir.

Selain itu juga muncul berbagai permasalahan di antaranya orang ketiga dalam hubungan, tuntutan menikah dari keluarga, dilema yang dirasakan subjek karena masih mencintai mantanya. Hal tersebut menyebabkan kekosongan dalam kebersamaan hubungan subjek, tidak bisa berkomunikasi secara terbuka dengan pasangan.

Subjek memiliki harapan yaitu hanya menjadikan status palsu jika subjek menikah dengan lawan jenis. Karena subjek ingin menikah dengan dengan sesama jenis, orang yang ingin dinikahinya adalah mantannya. Skema Interpretasi Cinta $\mathrm{C}$ tergambar di gambar 3.

\section{HASIL DAN PEMBAHASAN}

Dari hasil temuan penulis dari lapangan berkaitan dengan fenomena cinta lesbian di Kudus, dua subjek yaitu A dan B memiliki pengalaman cinta sejenis sebelumnya, sedangkan subjek $\mathrm{C}$ untuk pertama kalinya baru memiliki pengalaman cinta dengan sejenis. Untuk pengalaman cinta mereka yang sekarang bermula dari keintiman yang terjalin di antara masingmasing subjek kemudian muncul hasrat dan komitmen sejalan dengan hubungan cinta yang mereka jalani.

Pengalaman cinta subjek pertama, A, dialami ketika subjek lulus sarjana dan mulai bekerja. Subjek didekati oleh teman kerjanya, komunikasi terjalin kemudian timbul rasa takut dan penasaran. Dari rasa penasaran tersebut subjek menyadari perasaan cintanya untuk sejenis. Subjek 
mengaku mencintai pasangan sejenis pertamanya.

Pengalaman cinta subjek pertama, A, dialami ketika subjek lulus sarjana dan mulai bekerja. Subjek didekati oleh teman kerjanya, komunikasi terjalin kemudian timbul rasa takut dan penasaran. Dari rasa penasaran tersebut subjek menyadari perasaan cintanya untuk sejenis. Subjek mengaku mencintai pasangan sejenis pertamanya.

Selanjutnya pengalaman cinta pertama subjek kedua, B, dialami sejak tahun 2007 ketika subjek remaja. Subjek bertemu dengan cinta pertamanya dari seorang teman yang memperkenalkan mereka. Subjek mengaku awalnya hanya merasa kagum dan senang, namun kemudian timbul rasa suka yang tidak biasa, subjek menyadari bahwa dirinya menyukai sesama jenis dan rasa itu timbul dari dalam hatinya. Pengalaman cinta pertama subjek hanya berjalan dua bulan. Subjek memiliki tujuh pengalaman cinta sampai yang sekarang. Untuk pasangan yang sekarang, subjek yang terlebih dahulu mendekati dan mengutarakan cintanya.

Kemudian untuk subjek ketiga, C, juga mempunyai pengalaman cinta pertama ketika remaja, tepatnya setelah subjek lulus SMP. Subjek didekati oleh teman perempuannya dan merasa penasaran. Setelah berkenalan, subjek merasa nyaman dan semakin merasa ingin berdekatan dengan teman perempuannya. Teman perempuannya mengutarakan isi hatinya dan subjek menerimanya karena subjek juga menyadari rasa cintanya. Subjek merasa lebih nyaman dengan sesama jenis. Pengalaman cinta subjek yang pertama berlangsung selama tiga tahun. Subjek memiliki tiga pengalaman cinta sampai sekarang. Untuk pasangan yang sekarang, subjek yang terlebih dulu mendekati.
Hasil penelitian oleh Bell dan Weinberg (Peplau \& Amaro 1982), dari 283 lesbian yang tinggal di San Fransisco menunjukkan tentang berapa lama hubungan lesbian yang pertama kali dilakukan. Wanita dalam penelitian ini rata-rata berumur 22 tahun, ketika mereka mempunyai "hubungan menetap" yang pertama. Hampir 90\% koresponden mengatakan mereka telah "jatuh cinta" dengan pasangan pertama, dan tipikal dari hubungan pertama berlangsung selama rata-rata satu hingga tiga tahun. Kurang dari $8 \%$ memiliki hubungan pertama yang berakhir dalam tiga bulan atau kurang dari itu.

Pada subjek A, B, dan C mengungkapkan bahwa mereka jatuh cinta dengan pasangan sejenis pertama mereka. Namun hanya subjek A dan $\mathrm{C}$ yang hubungan cinta sejenis pertamanya berlangsung selama lebih dari satu tahun. Sedangkan subjek B hanya berlangsung selama 2 bulan.

Masih dalam hasil penelitian yang sama, hampir setengah dari sampel lesbian berkulit putih berusia rata-rata 35 tahun, mayoritas dari mereka memiliki kurang dari 10 pasangan seksual lesbian selama hidup mereka (Bel dan Weinberg, dalam Peplau \& Amaro, 1982). Ketiga subjek memiliki pasangan sejenis yang kurang dari 10. Subjek I memiliki satu pengalaman cinta sejenis, subjek kedua memiliki 7 pengalaman cinta sampai sekarang dan subjek ketiga memiliki 3 pengalaman cinta.

Berdasarkan teori segitiga cinta Sternberg (1986) bahwa cinta dapat dipahami melalui tiga komponen yaitu intimacy, passion, dan commitment. Dari hasil analisis ketiga subjek memiliki semua komponen yang ada dalam cinta sejenis mereka, namun terdapat perbedaaan dalam masing-masing komponen cinta yang ada dalam hubungan mereka. 
Komponen yang pertama adalah keintiman (intimacy), Sternberg dan Barnes (Putri, 2010) menemukan tiga subdimensi yang dapat lebih menjelaskan komponen intimacy. Ketiga subdimensi ini mengacu pada perbedaan level keintiman. Hasil analisis terhadap ketiga subjek ditemukan perbedaan level keintiman dalam cinta sejenis mereka. Pada subjek A dan B, merasakan kenyamanan dan ketenangan dengan pasangan, tidak bisa berpisah dengan pasangan \& selalu ingin bersama, merasa mendapat dukungan \& dorongan dari pasangan. Pada subjek $\mathrm{C}$ mencoba menghargai pasangan karena tidak bisa sendiri, merasa mendapat dukungan dari pasangan.

Kemudian level keintiman yang mengacu pada relasi antar keduanya, yang dapat menjadikan pasangan dan suatu hubungan spesial atau unik. Subjek A dan B menyukai kepribadian pasangan, menghargai pasangan dengan baik, memiliki keinginan untuk membahagiakan pasangan, menganggap penting orang yang dicintai. Hanya subjek $\mathrm{C}$ yang tidak terlalu menganggap penting pasangannya.

Sedangkan untuk level keintiman yang baik untuk satu sama lain dalam hubungan hanya muncul pada subjek B. Subjek B dengan pasangannya saling mencintai dan berbagi permasalahan satu sama lain. Kesimpulan untuk ketiga subjek hanya subjek B yang mencapai ketiga level keintiman sedangkan subjek A dan C hanya mencapai dua level keintiman.

Komponen yang kedua adalah hasrat (passion), merupakan elemen fisiologis yang menyebabkan seseorang merasa ingin dekat secara fisik, menikmati atau merasakan sentuhan fisik, ataupun melakukan hubungan seksual dengan pasangan hidupnya. Komponen passion juga mengacu pada dorongan yang mengarah pada romance, ketertarikan fisik, konsumsi seksual dan perasaan suka dalam suatu hubungan percintaan (Sternberg, dalam Marasabessy, 2008).

Dari hasil analisis yang penulis lakukan, pada subjek $\mathrm{A}, \mathrm{B}$ dan $\mathrm{C}$ menunjukkan dorongan ketertarikan fisik, yaitu subjek sama-sama menikmati daya tarik fisik dari pasangan sejenisnya. Kemudian untuk dorongan seksual, ketiga subjek melakukan kontak fisik dengan pasangan sejenisnya dari mulai berciuman sampai dengan melakukan hubungan seksual. Namun terdapat perbedaan dalam pencapaian kepuasan seksual mereka. Untuk subjek A bisa merasakan kepuasan ketika melakukan hubungan seksual dengan melihat pasangannya mencapai klimaks, pada subjek B bisa merasakan kepuasan dan mencapai klimaks dengan bergantian memuaskan satu sama lain, sedangkan pada subjek $\mathrm{C}$ bisa mencapai klimaks ketika dipuaskan oleh pasangan. Sedangkan untuk dorongan romansa hanya muncul pada subjek A, di mana subjek merasa selalu terkait, ingin selalu berdekatan dan tidak bisa jauh dari pasangan.

Hal tersebut sesuai dengan penelitian yang menunjukkan bahwa kebanyakan lesbian menemukan interaksi seksual mereka dengan wanita sangat memuaskan. Lesbian bercinta biasanya mengarah ke orgasme Sebagai contoh, lesbian dalam satu studi mengatakan bahwa mereka jarang mengalami kesulitan mencapai orgasme selama seks (Jay \& Muda dalam Peplau \& Amaro, 1982).

Penelitian fisiologis dari aspek seksual (Kinsey dkk., 1953; Master \& Johnson, dalam Peplau \& Amaro, 1982) telah menemukan tidak ada perbedaan dalam pola respon seksual lesbian dan perempuan heteroseksual. Tidak mengherankan bahwa mekanisme fisiologis gairah seksual dan orgasme sama untuk semua perempuan, 
terlepas dari orientasi seksual. Pemuasan seksual pada cinta lesbian biasanya berlangsung secara oral (dengan mulut) dan melalui alat kelamin bagian luar (Kartono, 1989). Hal ini seperti yang diungkapkan oleh subjek A dan B yang memperoleh kepuasan seksual dengan bergesekan, fingering dan oral. Ketiga subjek mendapat kepuasan seks dengan pasangan tetap mereka.

Penelitian memeriksa perilaku seksual bagi kebanyakan perempuan dalam hubungan lesbian yang menetap, seks yang menyenangkan adalah bagian dari hubungan tersebut. Di salah satu studi (Peplau dkk. dalam Peplau \& Amaro, 1982), tiga perempat lesbian berkata bahwa seks dengan pasangan tetap mereka "sangat memuaskan", dan hanya $4 \%$ yang mengatakan bahwa itu sama sekali tidak menyenangkan.

Kesimpulannya hanya subjek A yang terdapat ketiga dorongan hasrat seperti disebutkan di muka. Sedangkan untuk subjek $\mathrm{B}$ dan $\mathrm{C}$ hanya terdapat dua dorongan hasrat di dalam cinta mereka. Namun ketiganya sama-sama memiliki kepuasan secara seksual dengan pasangan sejenis mereka.

Komponen selanjutnya yang juga merupakan komponen cinta terakhir dalam teori Sternberg (1997) adalah komitmen. Sarwono \& Meinarno (2011) mengatakan bahwa seseorang berkomitmen untuk tetap bersama seorang pasangan dalam hidupnya. Sternberg (1997) mengatakan bahwa komponen ini memiliki aspek jangka pendek di mana seseorang memiliki keputusan untuk mencintai orang lain dan aspek jangka panjang di mana seseorang berkomitmen untuk mempertahankan cinta tersebut.

Dari hasil analisis yang penulis lakukan, untuk subjek A dan B mengatakan mencintai pasangan sejenis mereka sedangkan subjek $\mathrm{C}$ mengatakan hanya merasakan sayang pada pasangan sejenisnya. Selanjutnya pada subjek A memiliki keinginan untuk mempertahankan dan berusaha tetap bersatu meskipun tahu bahwa pasangannya belum sepenuhnya mencintainya. Kemudian subjek B ingin tetap berpacaran dan bisa hidup bersama selamanya meskipun pasangannya dijodohkan. Sedangkan pada subjek $C$ hanya menjalani hubungan dan berusaha mencintai dengan tulus, namun di sisi lain siap jika hubungannya berakhir.

Penelitian pada pasangan lesbian menunjukkan bahwa hubungan yang sukses adalah ketika mereka memiliki kualitas serta fungsi sama baik dengan hubungan heteroseksual. Banyak ilmuan yang telah menyimpulkan bahwa lesbian dan gay lebih banyak memilki kemiripan daripada perbedaan dengan perempuan dan pria heteroseksual (Scrivner, Eldridge \& Kurdek dalam Rose \& Eaton, 2012).

Bagi kebanyakan lesbian, hubungan cinta sangatlah penting. Bell dan Weinberg (Peplau \& Amaro, 1982) bertanya pada lesbian seberapa pentingnya bagi mereka untuk memiliki kehidupan permanen dengan pasangan homoseksual. Satu dari seperempat lesbian mengatakan bahwa ini adalah "hal yang paling penting dalam hidup" dan 35\% lainya mengatakan bahwa itu sangat penting. Satu dari 4 wanita mengatakan bahwa pengaturan tempat tinggal permanen itu tidak penting baginya.

Kesimpulannya pada subjek A dan B memiliki keinginan untuk hidup permanen dengan pasangan sejenisnya meskipun terdapat permasalahan dalam hubungan mereka. Sedangkan subjek C meskipun belum yakin dengan perasaannya karena subjek masih mencintai, merasa lebih 
nyaman dengan mantannya dan baginya tidak mudah untuk mencintai dengan tulus, namun subjek tetap memiliki komitmen untuk mencoba mencintai pasangannya dengan tulus.

Hubungan lesbian tidak kebal dari masalah. Konflik juga ternyata sering terjadi dalam hubungan cinta mereka. Sama seperti pasangan heteroseksual dan gay, pasangan lesbian juga memiliki permasalahan serupa tentang topik seperti keuangan, kasih sayang, jenis kelamin, kritik, dan tugas-tugas rumah tangga (Peplau \& Fingerhut dalam Rose \& Eaton, 2012). Jika seorang lesbian memiliki hubungan yang intim dengan pasangannya, suatu waktu akan terlihat adanya ketidaksesuaian antara keduanya. Konflik akan semakin mudah timbul bila interdependensi makin meningkat. Bila interaksi menjadi semakin kerap dan melibatkan berbagai kegiatan dan hal-hal yang semakin luas, peluang untuk munculnya ketidaksesuaian akan semakin besar (Sears, dkk. dalam Nurmala, Anam, \& Suyono, 2006).

Ketiga subjek memiliki konflik atau permasalahan dalam hubungan dan permasalahan internal yang berbeda-beda. Namun ada beberapa konflik yang sama. Permasalahan dalam hubungan yang muncul pada subjek A dan B yaitu perselingkuhan yang terjadi dalam hubungan cinta sejenis mereka. Perasaan cemburu hanya muncul pada subjek A karena pasangannya masih bertemu dengan mantannya. Kemudian konflik orang ketiga dalam hubungan cinta sejenis mereka muncul pada semua subjek. Sedangkan konflik perjodohan hanya muncul pada subjek $\mathrm{B}$, dalam hubungan cintanya pasangan sejenisnya dijodohkan oleh kedua orangtuanya.

Selanjutnya konflik internal yang muncul yaitu dari dalam diri lesbian ketika seorang perempuan lesbian harus memilih untuk tetap menjadi lesbian atau berhenti menjadi lesbian, hal ini disebabkan karena seorang lesbian sudah merasa tidak sesuai dan sering timbul konflik dengan pasangannya. Seorang perempuan yang normal sudah pasti akan memilih untuk melanjutkan kehidupannya dengan mencoba untuk berpikir mengenai masa depannya yaitu menikah dengan laki-laki namun bagi perempuan lesbian hal ini merupakan pilihan yang sangat sulit (Nurmala, Anam, \& Suyono, 2006).

Konflik internal yang muncul dari kedua subjek terdapat perbedaan dan kesamaan. Subjek A memiliki konflik internal yaitu trauma dengan lawan jenis dan tuntutan menikah yang datang dari keluarganya. Subjek B memiliki konflik internal berupa dilema karena masih mencintai mantannya terdahulu, akan tetapi di satu sisi subjek juga menyayangi pasangannya sekarang dan tidak mau ditinggal sendiri. Selain itu subjek juga dituntut untuk segera menikah oleh keluarganya karena sebagian saudaranya sudah menikah. Pilihan untuk menikah dengan lawan jenis merupakan hal yang sulit untuk dilakukan bagi subjek Adan C.

Berbagai konflik yang dialami oleh ketiga subjek di atas, berpengaruh pada hubungan cinta mereka. Pada subjek A, tidak dapat berkomunikasi secara intim, mendalam dan terbuka mengenai perasaan dengan pasangan. Subjek B membuat komunikasi \& intensitas mereka untuk bertemu semakin berkurang. Di sisi lain sikap plinplan dari pasangan sering menimbulkan konflik dalam hubungan. Sedangkan pada subjek C menyebabkan kekosongan dalam kebersamaan hubungan subjek, tidak bisa berkomunikasi secara terbuka dengan pasangan.

Selanjutnya dari hasil analisis, di samping berbagai konflik yang terjadi dalam 
hubungan cinta sejenis ketiga subjek. Muncul harapan subjek mengenai hubungan mereka. Setiap perempuan memiliki harapan untuk lebih baik mengenai masa depannya (Nurmala, Anam, \& Suyono, 2006). Ketiga subjek yang diteliti di atas memiliki harapan yang berbeda-beda mengenai masa depannya terutama tentang hubungan cinta mereka.

Ada yang berharap yang terbaik untuk pasangannya (menikah dengan lawan jenis), namun di sisi lain siap mengambil resiko dan bersedia menikahi pasangannya meskipun harus keluar Kudus bahkan ke luar negeri jika ada kesempatan seperti yang diharapkan subjek A. Lain halnya dengan subjek $B$ yang ingin menikah dengan lawan jenis yang sudah mengerti jati dirinya yang sebenarnya namun di sisi lain tetap ingin berhubungan dengan pasangan sejenisnya tanpa harus menikah. Sedangkan subjek $\mathrm{C}$ hanya menjadikan status palsu jika subjek menikah dengan lawan jenis. Karena subjek ingin menikah dengan sesama jenis, orang yang ingin dinikahinya adalah mantannya.

\section{KESIMPULAN}

Hasil penelitian mengenai cinta yang dimiliki lesbian menunjukkan bahwa fenomena cinta lesbian dalam penelitian ini, pada subjek A ketertarikannya terhadap sesama jenis sudah terlihat ketika subjek remaja. Dalam hubungan cinta lesbiannya, subjek mencapai dua level keintiman, tiga dorongan hasrat dan dua aspek komitmen. Namun di samping itu juga muncul berbagai permasalahan yang mempengaruhi hubungan subjek. Tetapi subjek juga masih memiliki harapan untuk bisa menikah dengan pasangan sejenisnya yang sekarang. Pada subjek B, ketertarikannya terhadap sejenis muncul dari rasa kagum terhadap perempuan. Pengalaman cinta terhadap sesama jenis dialami subjek sejak remaja. Subjek memiliki tujuh pengalaman cinta dan dalam cinta lesbiannya yang sekarang, subjek mencapai tiga level keintiman, dua level hasrat, dan dua aspek komitmen. Terdapat konflik yang berpengaruh pada hubungannya, tetapi subjek juga memiliki harapan untuk tetap bisa hidup bersama dengan pasangan sejenisnya. Kemudian pada subjek $\mathrm{C}$, ketertarikannya dengan sesama jenis juga muncul ketika remaja. Pengalaman cinta pertama dengan sejenis, dialami subjek ketika lulus SMP. Subjek memiliki tiga pengalaman cinta dan dalam cinta lesbiannya yang sekarang, subjek mencapai dua level ketintiman, dua dorongan hasrat dan dua aspek komitmen. Konflik juga muncul serta berpengaruh pada hubungannya dan subjek memiliki harapan untuk bisa menikah dengan sesama jenis tetapi yang ingin dinikahi subjek adalah mantan sejenisnya yang masih dicintai.

\section{DAFTAR PUSTAKA}

Budiarty, A. (2011). Gaya hidup lesbian (Studi kasus di kota Makassar). Skripsi Tidak Dipublikasikan. Makasar: Universitas Hasanuddin.

Fandina, F . (2012). Tipe percintaan gay. Skripsi Tidak Dipublikasikan. Bandung: Universitas Pendidikan Indonesia.

Handayani, A. T. (2010). Eksistensi komunitas lesbian yang terpinggirkan di kelurahan Kuta. Skripsi Tidak Dipublikasikan. Denpasar: Universitas Udayana.

Kartono, K. (1989). Psikologi abnormal dan abnormalitas seksual. Bandung: Mandar Maju.

Marasabessy, R . (2008). Perbedaan cinta berdasarkan teori segitiga cinta sternberg antara wanita dengan pria 
masa dewasa awal. Skripsi Tidak Dipublikasikan. Jakarta: Universitas Gunadarma.

Miles, M. B, \& Hubberman, A. M. (1992). Analisis data kualitatif. Jakarta: Universitas Indonesia Press.

Mutmainnah, M.B. \& Ismi. (2012). Perilaku komunikasi antarpribadi pasangan gay di kota Makassar Skripsi Tidak Dipublikasikan. Makassar : Universitas Hasanuddin.

Novena, T. O. M. (2011). Faktor-faktor yang mempengaruhi konsep diri pada butch. Skripsi Tidak Dipublikasikan. Semarang : Fakultas Psikologi Universitas Katolik Soegijapranata.

Nurkholis (2013). Faktor-faktor yang melatarbelakangi lesbian dan kondisi psikologisnya. Jurnal Online Psikologi Vol. 01 No. 01. 174-186.

Nurmala, D., Anam, C. \& Suyono, H. (2006). Studi kasus perempuan lesbian (butchy) di Yogyakarta. Humanitas: Indonesian Psychological Journal, 3, 1: 28 - 37.

Prima, J. P \& Ika, S. D. (2011). Kecemburuan dalam berpacaran pada gay dewasa dini. Skripsi Tidak Dipublikasikan. Medan: Fakultas Psikologi Sumatera Utara.

Peplau, L. A., \& Amaro, H. (1982). Understanding lesbian relationships. In W. Paul \& J. D. Weinrich, J.C.Gonsiorek \& M.E. Hotvedt., Homosexuality: social, psychological and biological issue. Beverly Hills, CA: Sage.

Putri, A. S. (2010). Cinta dan orientasi masa depan hubungan romantis pada dewasa muda yang berpacaran. Skripsi Tidak Dipublikasikan. Jakarta : Fakultas Psikologi Universitas Indonesia.

Rose, S. M., \& Eaton, A. A. (2012). Lesbian love, sex, and relationship. In D. Casteneda \& M. Paludi (Eds.). An essential handbook of women's sexuality. New York: Praeger.

Saragih, J. I. \& Irmawati. (2005). Fenomena jatuh cinta pada mahasiswi. Psikologia, 1, 1: 48-55.

Sarwono, S. W. \& Meinarno, E. A. (2009). Psikologi sosial. Jakarta: Salemba Humanika.

Setiawan, R. D. (2011). Gambaran kondisi jatuh cinta pada kaum homoseksual pria (gay). Skripsi Tidak Dipublikasikan. Yogyakarta: Fakultas Psikologi dan Ilmu Sosial Budaya UII.

Soewandi, H. (14 Juni 2010). Lesbian dalam pandangan psikiatrik. Kompas.

Sternberg, R. J. (1986). A triangular teory of love. Psychological Review 1986, Vol. 93, No. 2, 119-135.

Sternberg, R. J. (1997). Construct validation of a triangular love scale. European Journal of Social Psychology, 27: 313-335. 